\title{
Comparison of virulence of Coxiella burnetii isolates from bovine milk and from ticks
}

\author{
Elena Kocianová ${ }^{1}$, Elena Kováčová ${ }^{1}$ and Ivan Literák ${ }^{2}$ \\ ${ }^{1}$ Institute of Virology, Slovak Academy of Sciences, Dúbravská cesta 9, 84245 Bratislava, Slovakia; \\ ${ }^{2}$ Faculty of Veterinary Medicine, University of Veterinary and Pharmaceutical Sciences, Palackého 1-3, 61242 Brno, Czech \\ Republic
}

Key words: Coxiella burnetii, bovine milk, ticks, experimental animals, virulence

\begin{abstract}
Laboratory animals (mice and guinea pigs) were infected with the isolates of Coxiella burnetii (Derrick, 1939) obtained from bovine milk (M18 and M35) and the ticks Ixodes ricinus (Linnaeus, 1758) and Dermacentor marginatus (Sulzer, 1776) $\left(\mathrm{Kl}_{3}\right.$ and $\mathrm{Kl}_{6}$, respectively), and with the reference strain Nine Mile. Neither mortality nor lethality occurred with the mice. Antibody response in mice infected with isolates from milk was lower $(1: 16-512)$ than that from ticks $(1: 32-4096)$. Onset of seropositivity also occurred later - on the $10^{\text {th }}$ day post-infection (p.i.) for M18 and M35 in comparison with the $7^{\text {th }}$ day for $\mathrm{Kl}_{3}$ and $\mathrm{Kl}_{6}$. In guinea pigs, infection manifested by fever. The fever was less evident in guinea pigs infected with isolates from milk $\left(39.5-40.1^{\circ} \mathrm{C}\right)$ than in guinea pigs infected with isolates from ticks $\left(39.5-40.6^{\circ} \mathrm{C}\right)$. Partially engorged females of Dermacentor reticulatus (Fabricius, 1794) were inoculated with isolates $\mathrm{M} 18$ and $\mathrm{Kl}_{3}$. No differences in the multiplication of C. burnetii in haemocytes between these two isolates were ascertained.
\end{abstract}

The etiological agent of Q fever, Coxiella burnetii (Derrick, 1939), has been isolated in recent years from two sources in Slovakia and in the Czech Republic from bovine milk (Kocianová et al. 1993) on one hand, and from ticks Ixodes ricinus (Linnaeus, 1758), Dermacentor reticulatus (Fabricius, 1794), Dermacentor marginatus (Sulzer, 1776), Haemaphysalis inermis Birula, 1895 and Haemaphysalis concinna Koch, 1844 (Řeháček et al. 1991) on the other.

Although $C$. burnetii has been isolated on many occasions and the prevalence of antibodies in herds of cows ranges from $0.3 \%$ to $40 \%$ (Literák 1995, Literák and Řeháček 1996, Řeháček et al. 1998), in recent years we have not recorded human cases of Q fever caused by autochthonous strains of $C$. burnetii.

In order to assess the health importance of autochthonous strains of $C$. burnetii, it is necessary to know their virulence. As there is lack of information on the virulence of recent isolates of $C$. burnetii from Slovakia and from the Czech Republic, we have tried to characterise it by use of experimental infections.

\section{MATERIALS AND METHODS}

For the purpose of experimental infections, two isolates of C. burnetii obtained from the milk of seropositive cows were used: M18 from Pliešovce, Slovakia and M35 from Kunín, Czech Republic (Kocianová et al. 1993). These agents were isolated in the spleens of outbred laboratory mice (Swiss strain, Velaz, Prague, Czech Republic) and subsequently transferred and propagated in the yolk sacs of embryonated hen eggs (Brezina 1977). Agents of C. burnetii isolated from ticks ( $̌$ eháček et al. 1991) were also used: $\mathrm{Kl}_{3}$ from Ixodes ricinus and $\mathrm{Kl}_{6}$ from Dermacentor marginatus. Tick isolates were propagated in yolk sacs of embryonated hen eggs. To compare the virulence of these isolates, the virulent reference strain Nine Mile of $C$. burnetii phase I, which causes acute Q fever, was used. This strain was originally isolated from Dermacentor andersoni ticks (Davis and Cox 1938).

For the purpose of experimental infections, laboratory mice, guinea pigs and Dermacentor reticulatus ticks were used. Outbred laboratory mice (Swiss strain, colony of the Slovak Academy of Sciences, Dobrá Voda, Slovakia and Velaz, Prague, Czech Republic) and guinea pigs (colony of the Institute of Virology, Bratislava, Slovakia) were infected intraperitoneally (i.p.) with the isolates M18 and M35 in the third yolk passage $\left(\mathrm{EP}_{3}\right)$ suspension and with isolates $\mathrm{Kl}_{3}$ and $\mathrm{Kl}_{6}$ in the fourth yolk passage $\left(\mathrm{EP}_{4}\right)$ suspension with a dose of $0.5 \mathrm{ml}$ per animal. Stock suspensions of both milk and tick isolates were adjusted to contain the same amount of infection particles $10^{4} \operatorname{EID}_{50}$. A total of 105 infected mice and 15 as controls and 24 infected guinea pigs and 5 as controls were used.

The laboratory mice and guinea pigs were tested microscopically and serologically using microagglutination reaction (MAR) and enzyme-linked immunoadsorbent assay (ELISA). The temperature of the guinea pigs was monitored (daily during 14 days) and a temperature over $39.5^{\circ} \mathrm{C}$ (i.e., fever) was considered to be a clinical sign of infection. Microscopic examination (magnification: $\times 1000$ ) of $C$. burnetii was done using impressions of spleens, which were stained as described by Gimenéz (1964). Blood and spleen samples were taken from laboratory mice on the $7^{\text {th }}, 10^{\text {th }}$ and $14^{\text {th }}$ days p.i. and after that, every $7^{\text {th }}$ day until the $35^{\text {th }}$ day of infection (end of the experiment). Blood samples were taken from guinea pigs in the $4^{\text {th }}, 8^{\text {th }}$ and $12^{\text {th }}$ weeks p.i. 
Coxiella burnetii was also inoculated into 60 partially engorged adult female Dermacentor reticulatus ticks, after being confirmed as negative for $C$. burnetii using the haemocyte test (Řeháček et al. 1971). The ticks were infected intracoelomally (i.coel.) with $\mathrm{M} 18$ and $\mathrm{Kl}_{3}$ isolates, each in a dose of $10^{4} \mathrm{EID}_{50} / 25 \mu \mathrm{l}$. Multiplication of C. burnetii was detected microscopically in haemocytes, stained as described by Gimenéz (1964).

The serological investigations MAR and ELISA were carried out with the antigen derived from the standard strain of C. burnetii, Nine Mile (Institute of Virology, Bratislava, Slovakia). In MAR (Fiset et al. 1969) the titre of sera $\geq 16$ was considered positive. In ELISA test (Kováčová et al. 1987) titre was calculated from the mean value of negative sera plus $2 \times \mathrm{SD}$. Each value higher or equal was considered positive.

The fever in the guinea pigs was statistically evaluated by two-way analysis of variation (Zar 1996) on the statistical software package Programme STATGRAPHICS Plus, Version 7.

\section{RESULTS}

Laboratory mice. No mortalities were recorded and no visible clinical signs of illness were observed in mice infected with isolates from either milk or ticks. $C$. burnetii was detected in spleen on the fourth day after infection with milk isolates M18 and M35. On days 7, 10 and 14 , the number of $C$. burnetii particles increased. On the $21^{\text {st }}$ day only single particles were found and on the $28^{\text {th }}$ and $35^{\text {th }}$ days p.i., C. burnetii was not detected. In isolates from ticks (namely $\mathrm{Kl}_{6}$ ), tens to hundreds of particles were observed as early as the $4^{\text {th }}$ day p.i. On the $7^{\text {th }}, 10^{\text {th }}, 14^{\text {th }}$ and $21^{\text {st }}$ days the amount of C. burnetii particles rose in the vacuole of cytoplasm. On the $28^{\text {th }}$ day the number of particles decreased and on the $35^{\text {th }}$ day only a single particle could be found.

Antibodies against $C$. burnetii were detected (by MAR) in mice infected with the isolates M35 and M18 from the $10^{\text {th }}$ and $14^{\text {th }}$ days p.i., respectively, and during the course of monitoring, a maximum titre of $1: 512$ was reached (M18 on the $35^{\text {th }}$ day). For isolates $\mathrm{Kl}_{3}$ and $\mathrm{Kl}_{6}$, and the Nine Mile strain, antibodies were detected from the $7^{\text {th }}$ day. During the course of monitoring, a higher level of antibodies was reached for Nine Mile strain $\left(1:\right.$ 4096) and the $\mathrm{Kl}_{6}(1: 1024)$ and $\mathrm{Kl}_{3}(1:$ 4096) isolates (Fig. 1). As detected by ELISA, an antibody response after inoculation of isolate M18 occurred on the $10^{\text {th }}$ day, and on the $7^{\text {th }}$ day p.i. after $\mathrm{Kl}_{3}$ infection. We can conclude that isolates of $C$. burnetii from ticks $\left(\mathrm{Kl}_{3}\right)$ produce antibodies earlier and in higher titres than those from milk (M18) (Table 1).

Three weeks after inoculation of laboratory mice with isolates from milk, the amount of coxiellae was approxi-mately $2-4 \log$ lower $\left(10^{5.5}-10^{6} \mathrm{ID}_{50} / \mathrm{ml}\right)$ than after infections with isolates from ticks $\left(10^{8}-10^{10}\right.$ $\left.\mathrm{ID}_{50} / \mathrm{ml}\right)$. Similar differences were also found during titration of C. burnetii in yolk sacs of hen eggs.
Guinea pigs. In reaction to being infected with $C$. burnetii, guinea pigs developed a fever. After infection with M18 $(n=6)$ and M35 $(n=6)$ the fever appeared on the $5^{\text {th }}$ day p.i. (lasting an average of three days), with an average of $39.7^{\circ} \mathrm{C}$ in the case of M18 (range $39.5-40.1^{\circ} \mathrm{C}$ ) and $39.6^{\circ} \mathrm{C}$ in $\mathrm{M} 35$ (range $39.5-39.8^{\circ} \mathrm{C}$ ). In guinea pigs infected with isolates $\mathrm{Kl}_{3}(\mathrm{n}=6)$ and $\mathrm{Kl}_{6}(\mathrm{n}=6)$, the fever appeared on the $2^{\text {nd }}-3^{\text {rd }}$ days p.i. (lasting an average of six and a half days), with an average of $40.0^{\circ} \mathrm{C}$ for both isolates (range $39.5-40.3^{\circ} \mathrm{C}$ for $\mathrm{Kl}_{3}$ and $39.5-40.6^{\circ} \mathrm{C}$ for $\mathrm{Kl}_{6}$. The fever in guinea pigs infected with milk isolate M35 was lower than in guinea pigs infected with isolates from ticks. Differences in temperatures between all $C$. burnetii isolates were statistically significant according to twoway analysis of variation $\left(\mathrm{F}=95.438, \mathrm{df}_{1}=3, \mathrm{df}_{2}=160\right.$, $\mathrm{P} \leq 10^{-5}$ ). MAR-detected antibodies were found for both types of isolates during the set sampling period, and the level of titres achieved was different. Two months p.i. with M18 and M35 the antibodies had fallen to titres 1: 16-32. During this time, titres rose to $1: 64-512$ for tick isolates. Three months p.i. the titre levels still differed (Table 2).

Dermacentor reticulatus ticks. In ticks inoculated with isolate M18 the prevalence of positive specimen was high (30 positive/30 tested) and the proportion of infected haemocytes was almost $100 \%$ after three weeks, as was the case in ticks infected with isolate $\mathrm{Kl}_{3}$ (30 positive/30 tested). In both cases, the haemocytes contained hundreds of cells of $C$. burnetii. Differences between the proportion of infected haemocytes were not found.

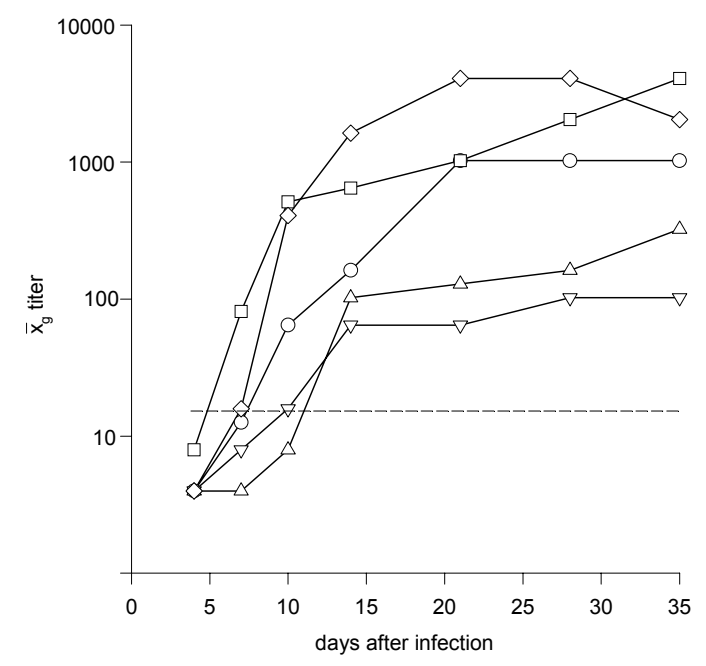

Fig. 1. Antibody response (MAR) in laboratory mice experimentally infected with $C$. burnetii.

$-\mathrm{O}-\mathrm{Kl}_{6} ;-\square-\mathrm{Kl}_{3} ;-\Delta-\mathrm{M} 18 ;-\nabla-\mathrm{M} 35 ;-\downarrow-$ Nine Mile; ------ level of positive titres 
Table 1. Antibodies to Coxiella burnetii in laboratory mice experimentally infected with isolates $\mathrm{M} 18$ from milk and $\mathrm{Kl}_{3}$ from Ixodes ricinus ticks (as revealed by ELISA).

\begin{tabular}{|c|c|c|c|c|}
\hline \multirow{2}{*}{$\begin{array}{l}\text { Days post } \\
\text { infection }\end{array}$} & \multicolumn{2}{|c|}{ Isolate M18 } & \multicolumn{2}{|c|}{ Isolate $\mathrm{Kl}_{3}$} \\
\hline & seroprevalence & titres & seroprevalence & titres \\
\hline 7 & $0 / 3 *$ & $\begin{array}{c}(100)^{+} \\
100^{++}\end{array}$ & $1 / 3$ & $\begin{array}{c}(100-500) \\
170.99\end{array}$ \\
\hline 10 & $1 / 3$ & $\begin{array}{c}(100-1000) \\
215.44\end{array}$ & $3 / 3$ & $\begin{array}{c}(500) \\
500\end{array}$ \\
\hline 14 & $3 / 3$ & $\begin{array}{c}(1000) \\
1000\end{array}$ & $3 / 3$ & $\begin{array}{c}(1000) \\
1000\end{array}$ \\
\hline 21 & $3 / 3$ & $\begin{array}{c}(1000-2000) \\
1587.40\end{array}$ & $3 / 3$ & $\begin{array}{c}(2000) \\
2000\end{array}$ \\
\hline 28 & $3 / 3$ & $\begin{array}{c}(1000) \\
1000\end{array}$ & $4 / 4$ & $\begin{array}{c}(2000) \\
2000\end{array}$ \\
\hline 35 & $3 / 3$ & $\begin{array}{c}(1000) \\
1000\end{array}$ & $1 / 1$ & $\begin{array}{c}(2000) \\
2000\end{array}$ \\
\hline
\end{tabular}

${ }^{*}$ positive/tested animals; ${ }^{+}$titres of sera (minimum-maximum); ${ }^{++}$mean of geometric titres

Table 2. Agglutination antibodies to Coxiella burnetii in guinea pigs experimentally infected with isolates from milk (M18, M35) and isolates from ticks $\left(\mathrm{Kl}_{3}, \mathrm{Kl}_{6}\right)$.

\begin{tabular}{|c|c|c|c|c|c|c|}
\hline \multirow{2}{*}{$\begin{array}{l}\text { C. burnetii } \\
\text { isolates }\end{array}$} & \multicolumn{2}{|c|}{4 weeks p.i. } & \multicolumn{2}{|c|}{8 weeks p.i. } & \multicolumn{2}{|c|}{12 weeks p.i. } \\
\hline & seroprevalence & titres & seroprevalence & titres & seroprevalence & titres \\
\hline M18 & $4 / 4^{*}$ & $\begin{array}{c}(32-256)^{+} \\
101.59^{++}\end{array}$ & $4 / 4$ & $\begin{array}{c}(16-32) \\
20.15\end{array}$ & $3 / 4$ & $\begin{array}{c}(16-32) \\
20.15\end{array}$ \\
\hline M35 & $4 / 4$ & $\begin{array}{c}(32-256) \\
101.59\end{array}$ & $4 / 4$ & $\begin{array}{c}(16-32) \\
25.39\end{array}$ & $3 / 4$ & $\begin{array}{c}(8-16) \\
12.69\end{array}$ \\
\hline $\mathrm{Kl}_{3}$ & $4 / 4$ & $\begin{array}{c}(128-256) \\
203.18\end{array}$ & $4 / 4$ & $\begin{array}{c}(64-512) \\
256\end{array}$ & $4 / 4$ & $\begin{array}{c}(32-256) \\
128\end{array}$ \\
\hline $\mathrm{Kl}_{6}$ & $4 / 4$ & $\begin{array}{c}(128) \\
128\end{array}$ & $4 / 4$ & $\begin{array}{c}(128-512) \\
203.18\end{array}$ & $4 / 4$ & $\begin{array}{c}(64-256) \\
161.26\end{array}$ \\
\hline Nine Mile & $4 / 4$ & $\begin{array}{c}(128-512) \\
203.18\end{array}$ & $4 / 4$ & $\begin{array}{c}(128-512) \\
256\end{array}$ & $4 / 4$ & $\begin{array}{c}(64-256) \\
161.26\end{array}$ \\
\hline
\end{tabular}

* positive/tested animals; ${ }^{+}$titres of sera (minimum-maximum); ${ }^{++}$mean of geometric titres

\section{DISCUSSION}

In Slovakia and in the Czech Republic, autochthonous strains of $C$. burnetii are present in many herds of cattle and in various natural foci (Literák and Řeháček 1996). The lack of clinical signs of illness in cattle herds can be explained by a low level of virulence of the strains circulating in the environment (Literák and Calvo Rodriguez 1994, Literák and Kroupa 1998). Experimen-tal infections with isolates from milk should contribute to clarifying the question of $\mathrm{C}$. burnetii circulation in the environment.

Testing of isolates of $C$. burnetii $\left(\mathrm{EP}_{3}\right)$ from bovine milk (M18 and M35) on pregnant sheep confirmed their low virulence (Kocianová et al. 1998). The animals did not fall ill and healthy lambs were born, although clinical Q fever did manifest itself in the sheep, mainly during the course of pregnancy. Agglutination antibodies were found 5-10 days p.i. with titres of 1 : 16128 in those sheep that had been infected intranasally or intravenously (i.v.). Complement-fixing (CF) antibodies were detected at the same time with titres of $1: 8-16$, and in the period around birth (8-11 weeks p.i.), they were found in all sheep in higher levels $(1: 16-32)$ and persisted until the end of the experiment, i.e., five months.

Martinov et al. (1989) tested the virulence of the $C$. burnetii strain Tchilnov $\left(\mathrm{EP}_{125}\right)$, originally isolated from sheep, on pregnant sheep infected i.v. The animals developed a fever, during which other clinical signs emerged. Lambs were stillborn or died within 24 hours post parturition. From the 8th day onwards, adult mothers had elevated CF antibodies (1:8-32), and the highest titre (1:256-512) appeared between 40-50 days p.i.

Another difference in the virulence between the investigated isolates is the course of the fever in guinea pigs. A lower level and shorter course of fever in the animals is typical of milk isolates. In this instance, it is of course necessary to emphasise that the $C$. burnetii 
Priscilla strain isolates from an aborting goat, which may cause chronic Q fever in humans, is also only mildly virulent for guinea pigs (Kazár et al. 1993).

Differences between isolates from milk (M18 and M35) and the reference strain of $C$. burnetii have also been found by Sekeyová et al. (1996). They compared the prototype Nine Mile and Priscilla strains with isolates from ticks and milk in a microimmunofluorescence test, an ELISA, and an immunoblot by the use of monoclonal antibodies against Nine Mile strain and Priscilla strain of an acute case and a chronic case of Q fever, respectively. When comparing monoclonal antibodies with isolates M18 and M35, to isolates from ticks and the prototype homologous strains, a markedly lower reaction was detected in the former, in all of the above mentioned tests.

In our experiments, the same results were obtained when comparing the virulence of C. burnetii isolates from ticks and from bovine milk with the reference strain Nine Mile. Seroconversion in the laboratory animals infected with the isolates from ticks and from Nine Mile was evident, and the intensity of the fever in the guinea pigs was different. Mice infected with the milk isolate demonstrated a lower number of $C$. burnetii particles in the spleen as compared with those injected with coxiellae originating from ticks. The species of tick from which the $C$. burnetii was isolated probably did not play a significant role.

The same results were demonstrated in our experiments comparing the virulence of C. burnetii isolates from ticks used with the reference strain Nine Mile. Seroconversion in infected laboratory animals was evident and the intensity of the infection was higher.

The spontaneous abatement of a focus that had been initiated by imported infected livestock, and that had spread to animals and people over several years without maintenance in ticks, is believed to have resulted in the disappearance of the disease in areas of Italy (Babudieri 1962). This hypothesis was also employed to explain the recession of acute forms of Q fever during the 1950s in former Czechoslovakia (Syrůček et al. 1958). Likewise, Pautov (1973) concluded that when $C$. burnetii is transferred from sheep and from cattle to cattle, it loses its virulence and finally becomes incapable of provoking infection. Decline of virulence of $C$. burnetii during the passages in the same species of tick was observed by Daiter and Gromova (1970). Klimchuk and Kushnir (1989) studied characteristics of two strains of $C$. burnetii from the natural foci of $\mathrm{Q}$ fever in north-western Ukraine. They monitored dynamics of antibody response and the course of fever in guinea pigs and laboratory mice. Strain Gishin, isolated from ixodid ticks, was characterised by high virulence and the Politsky strain, which was isolated from the common vole, considerably exceeded in the virulent properties.

SDS-PAGE, immunoblotting and serological methods were used to compare protein and lipopolysaccharide (LPS) profiles, and antigenicity of $12 \mathrm{C}$. burnetii strains isolated mostly from ticks, with three reference strains (originating from tick, human and goat). No significant differences in protein and LPS profiles were observed among tick strains from Europe and Mongolia. The LPS profiles of these strains appeared to be more related to those of Nine Mile strain associated with acute $\mathrm{Q}$ fever, than to those of strains associated with chronic Q fever. Reference Nine Mile strain gave double bands at approximately 14 and 16 $\mathrm{kD}$, which were absent in the chronic strains (Kováčová et al. 1994).

Our results may support the hypothesis that strains of C. burnetii, circulating in cattle herds without a prolonged or extensive tick intervention gradually decrease their virulence. The cattle stock from which the investigated isolate M35 originated was kept in closed stables during the lactation and no ticks were seen on these animals. The cows from another locality (isolates M18) grazed on pastures, however, no massive tick infestation was seen.

Acknowledgements. This work was supported, in part, by the Slovak Grant Agency for Science (grants No. 2/5031/98 and No. 2/1059/21). We would like to thank Prof. L. Jedlička, Faculty of Natural Science, Comenius University, Bratislava for statistical analysis and Mgr. D. Kučeráková, Bratislava for revision of the English.

\section{REFERENCES}

BABUDIERI B. 1962: Schicksal der tierischen Q Fieber Herde in nicht-endemischen Gebieten. $8^{\text {th }}$ Congress of the Austrian Soc. Microbiol. Hyg., Bregenz, pp. 30-33.

BREZINA R. 1977: Antigens and Immunity in Q Fever. Veda, Bratislava, $95 \mathrm{pp}$.

DAITER A.B., GROMOVA M.I. 1970: Influence of the organism of Hyalomma asiaticum and Ornithodoros papillipes on the biological activity of $C$. burnetii. Tr. Inst. Epidemiol. Mikrobiol. Im. Pastera 37: 72-83. (In Russian.)
DAVIS G.E., COX H.R. 1938: A filterpassing infectious agent isolated from ticks. I. Isolation from Dermacentor andersoni, reactions in animals and filtration experiments. Public Health Rep. 53: 2259-2267.

FISET P., ORMSBEE R.A., SILBERMAN R., PEACOCK M., SPIELMAN S.H. 1969: A microagglutination technique for detection and measurement of rickettsial antibodies. Acta Virol. 13: 60-66.

GIMENÉZ D.F. 1964: Staining rickettsiae in yolk-sac cultures. Stain Technology 39: 135-140. 
KAZÁR J., LESNÝ M., PROPPER P., VALKOVÁ D., BREZINA R. 1993: Comparison of virulence for guinea pigs and mice of different Coxiella burnetii phase I strains. Acta Virol. 37: 437- 448.

KLIMCHUK N.D., KUSHNIR Z.G. 1989: Biological properties of the Coxiella burnetii isolated in the north-west of the Ukrainian SSR. Mikrobiol. Zh. 51: 60-67. (In Russian.)

KOCIANOVÁ E., KOVÁČOVÁ E., LITERÁK I., ŘEHÁČEK J. 1993: Some biological properties of $C$. burnetii strains isolated in Slovak and Czech Republics. Book of Abstr., Int. Conf. on Zoonoses, Oct. 1993, Piešt'any, Publ. Slov. Med. Assoc., p. 46.

KOCIANOVÁ E., LITERÁK I., KOVÁČOVÁ E. 1998: Experimental infection with isolates of $C$. burnetii from cows milk. Abstr. Book. $21^{\text {st }}$ Congr. Czech Soc. Microbiol. Hradec Králové, p. 41.

KOVÁČOVÁ E., GALLO J., SCHRAMEK S., KAZÁR J., BREZINA R. 1987: Coxiella burnetii antigens for detection of $\mathrm{Q}$ fever antibodies by ELISA in human sera. Acta Virol. 31: 254-259.

KOVÁČOVÁ E., VAVREKOVÁ M., LUKÁČOVÁ M., DAITER A.B., TOKAREVICH N.K., KARCEVA N.A., GORBACHEV E.N., ÚRVOLGYI J., KOCIANOVÁ E., ŘEHÁČEK J., KAZÁR J. 1994: Immunochemical and antigenic characterization of Coxiella burnetii strains isolated in Europe and Mongolia. Eur. J. Epidemiol. 10: 9. 15.

LITERÁK I. 1995: Prevalence of Coxiella burnetii infection in military training areas in the Czech Republic and Slovakia. Acta Vet. (Brno) 64: 179-186.

LITERÁK I., CALVO RODRIGUEZ B. 1994: Latent Q fever in cattle in Southern Moravia (Czech Republic). Centr. Eur. J. Public Health 2: 91-94.

Received 21 February 2000
LITERÁK I., KROUPA L. 1998: Herd-level Coxiella burnetii seroprevalence was not associated with herd-level breeding performance in Czech dairy herds. Prevent. Vet. Med. 33: 261-265.

LITERÁK I., ¿̌EHÁČEK J. 1996: Q-fever distribution and importance of this disease in the Czech Republic and in the Slovak Republic. Vet. Med. (Praha) 41: 45-63.

MARTINOV S.P., NEIKOV P., POPOV G.V. 1989: Experimental Q fever in sheep. Eur. J. Epidemiol. 5: 428-431.

PAUTOV V.N. 1973: Ticks as environment of rickettsiae. Zh. Mikrobiol. Epidemiol. Immunol. 3: 74-77. (In Russian.)

ŘEHÁČEK J., BREZINA R., KOVÁČOVÁ E., ŽUPANČIČOVÁ M. 1971: Haemocyte test - an easy, quick and reliable method for the detection of rickettsiae in tick haemocytes. Acta Virol. 15: 237-240.

ŘEHÁČEK J., KOCIANOVÁ E., KOVÁČOVÁ E., KAPITANČIK B., JURČINA A., NAĎ O., LIČKO P. 1998: Occurrence of bovine coxiellosis in the district of Bardejov, eastern Slovakia. Vet. Med. (Praha) 43: 325330.

ŘEHÁČEK J., ÚRVÖLGYI J., KOCIANOVÁ E., SEKEYOVÁ Z., VAVREKOVÁ M., KOVÁČOVÁ E. 1991: Extensive examination of different tick species for infestation with C. burnetii in ia. Eur. J. Epidemiol. 7: 299-303.

SEKEYOVÁ Z., KOVÁČOVÁ E., KAZÁR J. 1996: Attempt to differentiate Coxiella burnetii isolates with the use of two monoclonal antibodies. In: J. Kazár and R. Toman (Eds.), Rickettsiae and Rickettsial Diseases. Proc. Vth Symp. Stará Lesná, Sept. 1-6, p. 446.

SYRŮČEK L., SOBĔSLAVSKÝ O., GUTVIRTH I. 1958: Isolation of Coxiella burnetii from human placentas. J. Hyg. Epidemiol. Microbiol. Immunol. (Prague) 2: 29-35.

ZAR J.H. 1996: Biostatistical Analysis. 3rd Edition. Prentice Hall Int., London etc., pp. X, 11, 19, 21, 205, 662.

Accepted 18 January 2001 